\title{
PENGUJIAN DAMPAK SISTEM INSENTIF DAN ORIENTASI KOGNITIF TERHADAP KINERJA KELOMPOK: STUDI DI INDONESIA
}

\author{
Siti Muslihah ${ }^{1}$, Sakina Nusarifa Tantri ${ }^{2}$ \\ 1,2 Program Studi Akuntansi/Departemen Ekonomika dan Bisnis/Sekolah Vokasi/Universitas Gadjah Mada, Indonesia \\ Email: 1'siti.muslihah@ugm.ac.id \\ Email: ${ }^{2}$ sakina.tantri@ugm.ac.id
}

\begin{abstract}
ABSTRAK
Penelitian ini bertujuan untuk mengetahui bagaimana kinerja individu berdasarkan orientasi kognitifnya terhadap sistem insentif. Penelitian ini mengacu pada penelitian terdahulu (Naranjo-Gil et al., 2012) yang menguji hal serupa dengan kebaruan bahwa penelitian ini dilakukan di Indonesia yang memiliki kultur berbeda dengan negara asal penelitian terdahulu. Metode yang digunakan dalam penelitian ini yakni studi kasus dengan responden mahasiswa berlatar belakang bidang ekonomi. Penelitian ini menghasilkan beberapa kesimpulan. Pertama, perilaku individu dalam menyelesaikan tugas cenderung sesuai dengan orientasi kognitif yang mereka miliki. Kedua, kelompok dengan orientasi kognitif individualis memberikan kinerja yang berbeda dengan kelompokyang memiliki orientasi kognitif kolektivis ketika diberikan insentif dengan sistem team-based structure. Ketiga, kelompok dengan orientasi kognitifindividualisme memberikan kinerja yang berbeda dengan kelompok yang memiliki orientasi kognitif collectivism ketika diberikan insentif dengan sistem individual-based structure. Sistem pemberian insentifyang paling tepat digunakan untuk meningkatkan kinerja kelompok dengan memperhatikan orientasi kognitif anggota kelompok adalah sistem insentif kelompok.
\end{abstract}

Kata kunci: akuntansi, individualisme, insentif, kolektivisme, studi kasus.

\section{PENDAHULUAN}

\section{Latar Belakang}

Organisasi memiliki tujuan untuk selalu meningkatkan kinerja dan mempertahankan kelangsungan kegiatan usahanya. Mempertahankan dan mengembangkan keunggulan kompetetif selalu dilakukan agar tujuan yang diharapkan dapat tercapai. Salah satu strategi yang dilakukan organisasi untuk mempertahankan dan mengembangkan keunggulan kompetetitifnya adalah dengan menerapkan struktur kinerja berbasis kelompok (Chenhall, 2008). Individu memiliki keterbatasan dalam pengembangan dan pemecahan masalah yang kompleks. Struktur berbasis kelompok diharapkan memberikan kontribusi yang lebih baik jika dibandingkan dengan struktur individu. Hal tersebut dikarenakan di dalam struktur kelompok memungkinkan terjadinya koordinasi dan kooperasi dalam setiap proses dan tindakan agar organisasi lebih fleksibel sehingga dapat mencapai tujuannya dengan lebih baik (Towry, 2003). Pemecahan masalah dan pencapaian target kinerja dalam kelompok dapat dilakukan lebih optimal karena terjadi pertukaran dan kontribusi ide serta diskusi antaranggota kelompok.

Akan tetapi pada praktiknya, struktur berbasis kelompok tidak selalu memberikan jaminan dapat meningkatkan kinerja organisasi. Kelompok yang terdiri atas beberapa individu juga rentan terhadap konflik antaranggota kelompok. Perbedaan latar belakang, orientasi, tujuan individu, dan kepentingan, membuka peluang terjadinya konflik sehingga mengakibatkan kinerja kelompok menjadi tidak optimal. Peluang konflik dalam pengambilan keputusan dapat mengakibatkan kinerja menjadi kurang optimal dan buruk (Denison, et al, 1996). Namun demikian, kinerja kelompok harus dapat berlanjut dan meningkat.

Salah satu yang dapat memotivasi kinerja kelompok adalah adanya sistem insentif kolektif (kelompok). Sistem insentif kolektif diyakini dapat memotivasi kinerja dan mengurangi potensi pelalaian terhadap kinerja kelompok dari masing-masing individu di dalam kelompok tersebut (Kelly, 2010). Hanya saja, di samping sistem insentif kolektif yang diterapkan, dalam organisasi juga menerapkan sistem insentif individu. Oleh karena itu, terkadang memunculkan persaingan dan konflik antarkaryawan, alih-alih meningkatkan semangat kebersamaan, kooperasi, dan menciptakan lingkungan yang kondusif dalam kelompok (Parker, et al, 2009).

Hofstede (1980) menyatakan bahwa orientasi kognitif manusia dapat dikategorikan menjadi 
individualis dan kolektivis. Masyarakat individualis menekankan bahwa mereka merasa memiliki otonomi, independensi emosional, inisiatif individual, hak atas privasi, pencarian kepuasan, keamanan finansial, kebutuhan pertemanan khusus, dan universalisme. Sebaliknya, masyarakat kolektivis menekankan identitas kolektif, ketergantungan emosional, solidaritas kelompok, sharing, hak dan kewajiban, kebutuhan bersama, keputusan kelompok, dan partikularisme. Orientasi kognitif individualis dan kolektivis memberikan nilai yang berbeda ketika manusia berada di tempat kerja atau dalam sebuah organisasi. Atau dengan kata lain, orientasi kognitif seorang karyawan merupakan faktor utama yang dapat mempengaruhi perilaku individu dalam kelompok.

Naranjo-Gil et al. (2012) menganalisis perbedaan pandangan peran sistem insentif pada kinerja kelompok dan mengkombinasikannya dengan orientasi kognitif manusia, yakni individualis dan kolektivis. Selain itu, penelitian mencoba menyelaraskan antara sistem insentif dan orientasi kognitif dalam kelompok. Hasil analisis penelitian ini menunjukkan bahwa individu-individu dalam kelompok yang memiliki orientasi kolektivis mampu mencapai kinerja lebih baik daripada kelompok yang didominasi individu dengan orientasi individualis, terlepas dari sistem insentif yang digunakan. Sedangkan variasi sistem insentif ternyata tidak memberikan efek yang signifikan pada kinerja kelompok dengan orientasi kognitif yang berbeda.

Berbagai hasil penelitian terkait sistem insentif, orientasi kognitif, dan pencapaian kinerja kelompok menjadi fokus dalam penelitian ini. Mereplikasi penelitian Naranjo-Gil et al. (2012), penelitian ini setting penelitian di Indonesia. Sehingga diharapkan memberikan kontribusi dalam memperkaya khasanah ilmiah dan memberikan manfaat untuk mengevaluasi sistem insentif agar dapat secara optimal memotivasi kinerja karyawan dengan orientasi kognitif yang beragam.

\section{Identifikasi Masalah}

Permasalahan yang muncul dalam penelitian ini terkait dengan kinerja individu yang didasarkan atas orientasi kognitif yang dimiliki. Seperti yang telah dijelaskan pada bagian sebelumnya, orientasi kognitif terdiri atas individualis dan kolektivis. Permasalahan yang akan diteliti pada penelitian ini adalah mengenai motivasi kinerja individu berdasarkan orientasi kognitifnya terhadap sistem insentif. Hal ini akan memungkinkan penggunaan sistem insentif paling efektif yang digunakan dalam organisasi.

\section{Tujuan Penelitian}

Penelitian ini memiliki tujuan utama menilai sistem insentif dan orientasi kognitif terhadap kinerja kelompok. Secara spesifik, tujuannya adalah

1. mengetahui apakah kelompok dengan orientasi kognitif individualism memberikan kinerja yang berbeda dengan kelompok yang memiliki orientasi kognitif collectivism ketika diberikan insentif dengan model team-based structure,

2. mengetahui apakah kelompok dengan orientasi kognitif individualism memberikan kinerja yang berbeda dengan kelompok yang memiliki orientasi kognitif collectivism ketika diberikan insentif dengan model individual-based structure,

3. mengetahui sistem pemberian insentif manakah yang efektif digunakan untuk meningkatkan kinerja kelompok dengan memperhatikan orientasi kognitif anggota kelompok.

\section{Tinjauan Pustaka}

\section{Insentif dan Kinerja}

Naranjo-Gil et al. (2012) merangkum definisi sistem insentif sebagai seluruh praktik atau teknik yang digunakan oleh perusahaan untuk memastikan perilaku yang pantas dari karyawan, dengan tujuan meningkatkan produktivitas karyawan secara khusus, dan kinerja organisasional secara umum. Insentif merupakan salah satu faktor yang mendorong meningkatnya semangat kerja dalam rangka pencapaian tujuan perusahaan dengan membangun harapan agar karyawan dapat menghasilkan tingkat prestasi lebih baik daripada yang ditentukan (Evi, 2009).Penelitian sebelumnya terkait hubungan insentif dengan kinerja telah dilakukan oleh Erbasi dan Arat (2012) tentang pengaruh insentif finansial dan non-finansial terhadap kepuasan kerja di Turki, dan dihasilkan bahwa terdapat hubungan signifikan antara insentif finansial dan non-finansial dengan kepuasan kerja karyawan, dimana pengaruh insentif finansial memiliki pengaruh lebih kuat terhadap kepuasan kerja daripada insentif non-finansial. Sementara itu, Hoffman dan Rogelberg (1998) melakukan reviu atas literatur-literatur terkait dengan 
insentif dan menyimpulkan beberapa kategori utama dalam praktik insentif kelompok, antara lain:

a. Profit sharing/gain sharing

Pada sistem sharing ini, insentif kelompok berkaitan erat dengan outcome kelompok, misalnya profit dan produktivitas organisasi, kepuasan pelanggan, dan lain-lain. Secara lebih spesifik, outcome organisasi dievaluasi dan diberi penghargaan ketika organisasi menghasilkan profit dengan jumlah tertentu.

b. Team goal-based incentive system

Dalam sistem insentif ini, organisasi membentuk sasaran atau target untuk setiap tim yang dipercaya mampu menghasilkan outcome kinerja yang efektif (misalnya target produksi, target pelayanan kepada pelanggan, dll).

c. Team discretionary bonus system

Sistem insentif ini mirip dengan goal-based incentive system yang mengevaluasi outcome tim, tetapi memiliki perbedaan yaitu tim tidak diberikan target-target sebelumnya.

d. Team member skill incentive system

Berbeda dengan sistem-sistem insentif yang lain, sistem ini menekankan pada keterampilan tim, bukan outcome. Keterampilan dievaluasi ketika menentukan apakah reward akan diberikan. Ketika tim dinilai memiliki peningkatan keterampilan tertentu (biasanya dinilai oleh supervisor), tim diberi reward, tanpa memperhatikan outcome tim.

e. Team member goal incentive and merit system Sistem insentif ini mengevaluasi kontribusi dan outcome dari anggota-anggota tim ketika mendistribusikan reward. Progres ketercapaian tujuan dari anggota tim dievaluasi oleh penilai kinerja.

\section{Orientasi Kognitif}

Hofstede (1980) dalam artikelnya menyatakan bahwa orientasi kognitif manusia dapat dikategorikan menjadi individualis dan kolektivis. Individualis/ kolektivis menjelaskan perbedaan budaya dalam perilaku sosial. Masyarakat individualis menekankan bahwa mereka merasa memiliki otonomi, independensi emosional, inisiatif individual, hak atas privasi, pencarian kepuasan, keamanan finansial, kebutuhan pertemanan khusus, dan universalisme. Sebaliknya, masyarakat kolektivis menekankan identitas kolektif, ketergantungan emosional, solidaritas kelompok, sharing, hak dan kewajiban, kebutuhan bersama, keputusan kelompok, dan partikularisme. Hal ini juga seperti dinyatakan oleh Bochner dan Hesketh (1994), bahwa individualisme/kolektivisme mengacu pada hubungan antar individual dengan kolektivitas di dalam kelompok masyarakat. Kolektivis memiliki kontak non-formal yang lebih banyak dengan rekanrekan kerjanya, mampu memahami staf dengan lebih baik, dan cenderung bekerja secara tim.

Bukti-bukti yang diperoleh dari penelitianpenelitian sebelumnya menunjukkan bahwa komponen individualis/kolektivis yang berbeda memiliki hubungan dengan budaya. Oyserman et al. (2002), seperti yang diungkapkan dalam penelitian Chen dan West (2008), melakukan meta-analisis yang hasilnya mengindikasikan bahwa terdapat perbedaan budaya pelajar yang berasal dari Jepang dan Amerika Serikat. Secara spesifik, hasil penelitian tersebut menyimpulkan bahwa competitveness dan uniqueness mempengaruhi tingkat individualisme global dalam tujuan yang berbeda.

\section{Kajian Penelitian Terdahulu}

Terdapat dua teori yang digunakan di dalam penelitian sebelumnya oleh Naranjo-Gil et al., (2012) terkait dengan orientasi seseorang dalam berperilaku, khususnya terhadap sesuatu yang dapat memunculkan motivasi individu dalam melakukan pekerjaannya, yaitu kolektivisme dan individualisme. Teori individualisme-kolektivisme membedakan dua perilaku utama berdasarkan jenis kecenderungan di dalam manusia. Kolektivisme adalah orientasi terhadap hubungan personal-kelompok, yang hubungan tersebut dipandang sebagai hubungan permanen, sedangkan individualisme mengacu pada kondisi dimana seorang pribadi mengutamakan kepentingan pribadinya di atas kepentingan kelompok (Triandis dan Gelfand, 1998; Wagner, 1995). Orang-orang yang memiliki orientasi individualis cenderung kurang memiliki hubungan emosional dengan rekan satu kelompoknya, dan sikap tersebut dapat menimbulkan ketegangan dan konflik di dalam kelompok sehingga kinerja kelompok akan menurun. Dengan demikian, dapat diasumsikan bahwa kelompok yang terbentuk dari sekumpulan orang-orang individualis akan memiliki kinerja yang buruk ketika pekerjaan membutuhkan interaksi dan kerjasama di antara anggota kelompok karena 
orang individualis kurang kooperatif dibandingkan kolektivis di dalam sebuah kelompok. Sebaliknya, orang-orang kolektivis lebih mampu bekerjasama dan melakukan kinerja yang lebih baik daripada kelompok dengan kolektivisme lebih rendah di antara anggotanya.

Sistem insentif yang sesuai dengan orientasi kognitif telah diteliti sebelumnya oleh Earley (1989) dan menemukan bahwa sampel yang merupakan orang China (sampel kolektivis) memiliki kinerja yang lebih baik pada lingkungan kerja yang juga kolektivis, sementara sampel yang berasal dari Amerika Serikat (sampel individualis) memiliki kinerja yang lebih baik di dalam lingkungan individualis. Hal ini menunjukkan bahwa lingkungan kerja dan orientasi kognitif individu berperan penting dalam melakukan pekerjaan, sehingga mempengaruhi baik buruknya kinerja akhir yang dihasilkan. Pengaruh baik buruknya kinerja juga dipengaruhi oleh insentif yang diberikan. Naranjo-Gil et al. (2012) mengutip penelitian Kim et al. (1994) yang menunjukkan bahwa orang individualis menuntut insentif yang juga berorientasi individu karena mereka merasa terpisah dan berbeda dari tim. Sementara itu, kolektivis mementingkan ketercapaian tujuan kelompok daripada individu, dan lebih menginginkan sistem insentif yang berbasis kelompok. Dari uraian tersebut, dapat dikembangkan asumsi bahwa sistem insentif yang sesuai dengan orientasi kognitif masing-masing individu akan meningkatkan kinerja individu tersebut sehingga tujuan tim akan tercapai dengan baik. Dengan kata lain, anggota kelompok dengan orientasi kognitif yang berbeda dimotivasi oleh jenis skema insentif yang berbeda juga (Naranjo-Gil et al., 2012). Jika orientasi kognitif individu dengan skema sistem insentif yang ada tidak cocok, maka akan diprediksi bahwa kinerja kelompok tidak akan optimal.

\section{METODE PENELITIAN Desain Penelitian}

Penelitian ini dilakukan menggunakan metode kualitatif studi kasus. Studi kasus merupakan metodologi riset yang bertujuan untuk memperoleh perspektif mengenai suatu kejadian, situasi, atau proses pada satu waktu tertentu (Cooper dan Schindler, 2006). Penelitian ini dilakukan pada mahasiswa ekonomi yang sedang menempuh pendidikan vokasi. Penelitian ini menggunakan tiga indikator yang terdiri atas sistem insentif, kinerja kelompok, dan orientasi kognitif. Indikator insentif dibagi menjadi dua, yaitu sistem individual dan sistem kelompok. Indikator kinerja dilihat dari banyaknya kasus yang dapat diselesaikan dalam satu tim. Indikator kognitif dibagi menjadi dua, yaitu individualis dan kolektivis.

\section{Prosedur Penelitian}

Sebelum dilakukan pengamatan, mahasiswa diminta untuk mengisi kuesioner terkait dengan orientasi kognitif individu. Tujuan dari pengisian kuesioner ini adalah sebagai bantuan untuk mengelompokkan mahasiswa ke dalam orientasi kognitif yang mereka miliki. Pengukuran dan instrumen kuesioner yang digunakan dalam kuesioner ini sesuai dengan instrumen yang dikembangkan oleh Triandis (1998). Setelah itu, mahasiswa dikelompokkan menjadi dua kelompok orientasi kognitif, yaitu kelompok kolektivis dan individualis. Setelah dikelompokkan ke dalam dua kelompok orientasi kognitif tersebut, mahasiswa dibagi lagi ke dalam dua sistem insentif, yaitu sistem insentif berbasis kelompok dan sistem insentif individual untuk masing-masing kelompok kognitif. Pada penelitian ini, sistem insentif akan diberikan dalam bentuk nilai.

Pengamatan dilakukan di kelas pada saat perkuliahan sedang berlangsung. Mahasiswa diberikan tugas oleh dosen untuk menyelesaikan kasus. Kasus yang diberikan sesuai dengan mata kuliah yang sedang berlangsung. Setiap tim terdiri atas empat orang, dan setiap orang diberikan kasus yang berbeda untuk dikerjakan. Masing-masing tim diberitahukan tanggungjawabnya masing-masing, bertanggung jawab atas tugas individu atau betanggung jawab atas tugas kelompoknya. Pada saat mereka mengerjakan tugas yang diberikan, dilakukan pengamatan terhadap beberapa hal terkait dengan perilaku individu di dalam tim tersebut. Kinerja setiap tim juga akan dinilai berdasarkan jumlah kasus yang dapat diselesaikan. Insentif berupa nilai kemudian diberikan berdasarkan tanggung jawab yang diberikan kepada masingmasing tim.

\section{Teknik Analisis Data}

Dalam melakukan analisis data hasil pengamatan, penelitian ini membentuk pola dan mencari kesepadanan antara dua kategori yang 
digunakan serta melakukan interpretasi langsung (Stake, 1995), yaitu kategori individualis dan kolektivis. Pembentukan pola dilakukan dengan mengamati perilaku mahasiswa pada saat melakukan tugasnya. Perilaku yang diamati adalah apakah mereka mendiskusikan terlebih dahulu tugas yang diberikan atau tidak, bagaimana cara mereka bekerja, dan bagaimana interaksi antara anggota tim saat mereka bekerja.

Pengamatan tidak hanya dilakukan pada saat mereka melakukan tugasnya, tapi juga dilakukan terhadap hasil kinerja. Hasil kinerja dinilai berdasar jumlah kasus yang dapat mereka selesaikan pada saat perkuliahan berlangsung. Tugas dinilai sesuai dengan insentif yang telah diberitahukan, apakah menggunakan insentif individu atau insentif kelompok. Pengamatan terhadap hasil kinerja diperlukan untuk mengetahui sistem insentif yang lebih efektif digunakan dalam penyelesaian tugas. Permasalahan penelitian akan dapat terjawab dengan hasil dari pengamatan perilaku dan hasil kinerja kelompok. Hasil dari pengamatan akan menunjukkan sistem insentif mana yang lebih efektif memotivasi kinerja kelompok mahasiswa.

\section{HASIL DAN PEMBAHASAN Gambaran Penelitian}

Penelitian ini dilakukan dengan mengamati perilaku dan hasil kinerja mahasiswa pada saat melakukan tugas. Tugas diberikan dalam bentuk kasus yang harus diselesaikan oleh mahasiswa dalam kelas yang mereka ikuti. Subjek penelitian ini adalah mahasiswa yang berlatar belakang pendidikan ekonomi. Pengamatan dilakukan pada 56 mahasiswa, yang usianya berkisar antara 18 sampai 21 tahun. Mahasiswa-mahasiswa tersebut dikelompokkan berdasarkan orientasi kognitif yang mereka miliki, yaitu 7 tim individualis dan 7 tim kolektivis. Setiap kelompok orientasi kognitif kemudian dibagi menjadi dua metode pemberian insentif, yaitu insentif individual dan insentif kelompok. Pengamatan penelitian ini dilakukan pada saat perkuliahan sedang berlangsung.

\section{Hasil Penelitian}

Penelitian ini mengamati perilaku individu pada saat melakukan tugas serta hasil kinerjanya yang akan dinilai dengan insentif. Perilaku individu yang diamati adalah bagaimana tim memulai pengerjaan tugas, bagaimana cara mereka mengerjakan tugas, dan bagaimana kerja sama antar anggota tim pada saat melakukan tugas. Hasil pengamatan akan dijelaskan pada empat kategori tim yang berbeda, yaitu individualis dengan sistem insentif individual, individualis dengan sistem insentif kelompok, kolektivis dengan sistem insentif individual, dan kolektivis dengan sistem insentif kelompok.

Pada pengamatan tim individualis dengan sistem insentif individual, saat tim memulai mengerjakan tugas, mereka langsung bekerja menyelesaikan tugas mereka masing-masing tanpa berdiskusi terlebih dahulu dengan anggota yang lain. Pada saat menyelesaikan tugas, terdapat dua tim yang menyelesaikan tugas mereka masing-masing, dan satu tim yang sesekali terlihat membantu teman setimnya. Pada salah satu tim terlihat bahwa salah satu anggota tim menunjukkan keirian pada saat anggota timnya yang lain telah selesai mengerjakan tugasnya. Kerja sama mereka di dalam penyelesaian tugas juga terlihat kurang apabila dilihat dari interaksi antar anggota tim.

Pada pengamatan tim individualis dengan sistem insentif kelompok, saat memulai mengerjakan tugas, ketiga tim tersebut langsung bekerja menyelesaikan tugas mereka masing-masing tanpa berdiskusi terlebih dahulu dengan anggota yang lain. Pada saat menyelesaikan tugas ketiga tim fokus pada penyelesaian tugas mereka masing-masing. Pada salah satu tim, terdapat anggota yang membantu temannya dalam menyelesaikan tugas setelah dia selesai. Kerja sama mereka di dalam penyelesaian tugas juga terlihat kurang apabila dilihat dari interaksi antar anggota tim.

Pada pengamatan tim kolektivis dengan sistem insentif individual, saat memulai mengerjakan tugas, keempat tim tersebut langsung bekerja menyelesaikan tugas mereka masing-masing tanpa berdiskusi terlebih dahulu dengan anggota yang lain. Pada pelaksanaan tugas, terdapat dua kelompok yang bekerjasama, dan pada dua kelompok yang tidak tidak bekerjasama. Pada saat menyelesaikan tugas, terdapat dua tim yang menyelesaikan tugas mereka masing-masing, dan satu kelompok yang sesekali terlihat membantu teman sekelompoknya. Kerja sama mereka di dalam penyelesaian tugas juga terlihat sudah cukup baik apabila dilihat dari interaksi antar anggota tim.

Pada pengamatan tim kolektivis dengan sistem insentif kelompok, saat memulai mengerjakan tugas, 
keempat tim tersebut ada yang langsung bekerja menyelesaikan tugas dan ada yang mendiskusikan strategi terlebih dahulu. Sebagian besar dari mereka juga saling membantu dalam proses penyelesaian tugas. Pada pelaksanaan tugas, keempat tim saling berinteraksi dengan sesama anggota timnya. Pada saat menyelesaikan tugas, terdapat keempat tim menyelesaikan tugas mereka bersama-sama dan terlihat saling mendukung. Kerja sama mereka di dalam penyelesaian tugas juga terlihat baik apabila dilihat dari interaksi antar anggota tim.

Dari beberapa penjelasan mengenai hasil pengamatan di atas, maka dapat dilihat bahwa secara keseluruhan, kelompok orientasi kognitif individualis cenderung akan langsung memulai mengerjakan pekerjaan mereka masing-masing tanpa mendiskusikannya terlebih dahulu meskipun mereka bekerja dalam tim. Hanya terdapat satu tim yang saling membantu antar anggota tim tersebut, namun itu dilakukan setelah anggota tim tersebut fokus pada penyelesaian tugasnya sendiri. Hasil ini sejalan dengan penemuan Triandis dan Gelfand (1998); Wagner (1995) yang menyatakan bahwa individualisme mengacu pada kondisi dimana seorang pribadi mengutamakan kepentingan pribadinya di atas kepentingan kelompok. Pada kelompok orientasi kognitif kolektivis, perilaku mereka cenderung menyesuaikan dengan sistem insentif yang mereka terima. Pada saat mereka berada di bawah kondisi sistem insentif individual, pada awalnya mereka langsung melaksanakan tugasnya masing-masing tanpa berdiskusi dengan timnya. Namun di tengah perjalanan, mereka kemudian saling membantu antar anggota tim. Pada saat di bawah kondisi sistem insentif kolektif, beberapa mereka memulai tugasnya dengan mendiskusikan strategi penyelesaian terlebih dahulu. Mereka juga bekerja bersama-sama dalam menyelesaikan tugas. Hasil ini sesuai dengan penelitian Naranjo-Gil et al. (2012) yang menyatakan bahwa anggota kelompok dengan orientasi kognitif yang berbeda dimotivasi oleh jenis skema insentif yang berbeda juga.

Penelitian ini tidak hanya mengamati perilaku individu saat mereka menyelesaikan tugas, tapi juga menilai hasil kinerja mereka. Hasil kinerja dinilai dengan jumlah tugas yang dapat diselesaikan dalam kelompok. Hasil tugas yang dapat diselesaikan oleh masing-masing tim disajikan dalam tabel berikut.
Tabel 1. Hasil Penyelesaian Tugas

\begin{tabular}{lccc}
\hline & $\begin{array}{c}\text { Sistem } \\
\text { Insentif } \\
\text { Individual }\end{array}$ & $\begin{array}{c}\text { Sistem } \\
\text { Insentif } \\
\text { Kelompok }\end{array}$ & Jumlah \\
\hline Individualis & 5 & 8 & 13 \\
Kolektivis & 9 & 14 & 23 \\
\hline Jumlah & 14 & 32 & 36 \\
\hline
\end{tabular}

Tabel 1 menunjukkan jumlah tugas dalam bentuk kasus yang dapat diselesaikan oleh masingmasing kelompok. Dari tabel tersebut dapat dilihat bahwa kelompok orientasi kognitif kolektivis cenderung memiliki hasil kinerja yang lebih baik dari pada kelompok orientasi kognitif individualis, bahkan dapat menghasilkan dua kali lipat kinerja. Selain itu, dapat kita lihat juga bahwa penggunaan sistem insentif kelompok cenderung menghasilkan kinerja yang lebih baik dari pada penggunaan sistem insentif individual. Hasil tersebut konsisten pada kedua kelompok orientasi kognitif.

\section{KESIMPULAN}

Berdasarkan hasil pengamatan yang telah dilakukan, dapat diperoleh beberapa kesimpulan. Pertama, pengamatan perilaku individu dalam menyelesaikan tugas cenderung sesuai dengan orientasi kognitif yang mereka miliki. Kelompok dengan orientasi kognitif individualis cenderung langsung mengerjakan tugasnya-masing-masing, cenderung fokus pada penyelesaian tugas masingmasing, dan kurang memiliki kerja sama di dalam kelompoknya. Kelompok dengan orientasi kognitif kolektivis cenderung mendiskusikan strategi, serta menyelesaikan tugas dengan saling membantu.

Kedua, terdapat perbedaan signifikan antara kelompok dengan orientasi kognitif individualis memberikan kinerja yang berbeda dengan kelompok yang memiliki orientasi kognitif kolektivis ketika diberikan insentif dengan sistem team-based structure. Pada sistem ini, kelompok dengan orientasi kognitif kolektivis cenderung memiliki kinerja yang lebih baik dibandingkan dengan kelompok orientasi individualis. Ketiga, terdapat perbedaan signifikan antara kelompok dengan orientasi kognitif individualism memberikan kinerja yang berbeda dengan kelompok yang memiliki orientasi kognitif collectivism ketika diberikan insentif dengan sistem individual-based structure. Pada sistem insentif ini, kinerja kelompok orientasi kognitif kolektivis masih cenderung lebih baik apabila 
dibandingkan dengan kelompok berorientasi kognitif individualis, meskipun berada di bawah sistem insentif individu.

Kesimpulan terakhir dari penelitian ini menunjukkan bahwa sistem pemberian insentif yang paling tepat digunakan untuk meningkatkan kinerja kelompok dengan memperhatikan orientasi kognitif anggota kelompok adalah sistem insentif kelompok. Hal ini dibuktikan dengan hasil kinerja pada Tabel 1 yang menunjukkan bahwa kinerja kedua kelompok orientasi kognitif baik individualis atau kolektivis menghasilkan kinerja yang cenderung lebih baik pada sistem pemberian insentif kelompok. Kesimpulan penelitian ini diharapkan dapat berkontribusi dalam menentukan sistem penentuan insentif yang memotivasi kinerja organisasi agar dapat menghasilkan kinerja yang lebih baik.

\section{DAFTAR PUSTAKA}

Bochner, S; B. Hesketh. (1994). Power Distance, Individualism/Collectivism, and Job-Related Attitudes in a Culturally Diverse Work Group. Journal of Cross-Cultural Psychology, 25; 233.

Chen, F. F; S. G. West. (2008).Measuring Individualism and Collectivism: The Importance of Considering Differential Components, Reference Groups, and Measurement Invariance. Journal of Research in Personality, 42: 259-294.

Cooper, D. R.; P.S. Schindler. (2006). Business Research Method. New York, USA: McGrawHill.

Denison, D.R. 1996. What is the Difference Between Organizational Culture and Organizational Climate? A Native's Point of View on a Decade of Paradigm Wars. The Academy of Management Review, Vol .21 No.3, pp. 619654.

Earley, P; C. Gibson. (1998). Taking Stock in Our Progress on Individualism-Collectivism: 100 Years of Solidarity and Community. Journal of Management, 24: 265-304.

Evi, T. (2009). Kajian Teoritis Analisa Hubungan Pemberian Insentif dengan Semangat Kinerja
Karyawan. Seminar Nasional Informatika, UPN "Veteran" Yogyakarta, 23 Mei 2009.

Erbasi, A; T. Arat. (2012). The Effect of Financial and Non-financial Incentives on JobSatisfaction: An Examination of Food Chain Premises in Turkey. International Business Research; Vol. 5, No. 10.

Hoffman, J. R; S. G. Rogelberg. (1998). A Guide to Team Incentive Systems. Team Performance Management, Vol. 4, No. 1.

Hofstede, G. (1980). Motivation, Leadership, and Organization: Do American Theories Apply Abroad?. Organizational Dynamics, Summer 1980.

Naranjo-Gil, D; G. Cuevaz-Rodriguez; A. LopezCabrales; J. M. Sanchez. (2012). The Effects of Incentive System and CognitiveOrientation on Teams' Performance. Behavioral Research in Accounting, Vol. 24, No. 2, pp. 177-191.

Parker, R.S., D.L. Haytko, and C. M. Hermans. (2009). Individualism and Collectivism: Reconsidering Old Assumption. Journal of International Business Research, Vol. 8 No.1, pp. 127-139.

Stake, R. (1995). The art of case study research (pp. 49-68). Thousand Oaks, CA: Sage.

Towry, Kristy L. (2003). Control in a Teamwork Environment-The Impact of Social Ties on the Effectiveness of Mutual Monitoring Contracts. The Accounting Review: Vol. 78, No. 4, pp. 1069-1095.

Triandis, H. C; M. J. Gelfand. (1998). Converging Measurement of Horizontal and Vertical Individualism and Collectivism. Journal of Personality and Social Psychology, 74 (1): 118-128.

Wagner, J.A. (1995). Studies of IndividualismColelctivism: Effects on Cooperation in Groups. Academy of Management Journal, Vol. 38 No.1, pp. 52-172. 